\title{
Effect of Moisture on Thermal Inactivation of Soilborne Pathogens Under Structural Solarization
}

\author{
Eli Shlevin, Yitzhak Mahrer, and Jaacov Katan
}

First and third authors: Department of Plant Pathology and Microbiology; and second author: Seagram Center for Soil and Water Sciences, The Hebrew University of Jerusalem, Faculty of Agricultural, Food and Environmental Quality Sciences, Rehovot 76100, Israel. Accepted for publication 25 September 2003.

\section{ABSTRACT}

Shlevin, E., Mahrer, Y., and Katan, J. 2004. Effect of moisture on thermal inactivation of soilborne pathogens under structural solarization. Phytopathology 94:132-137.

Structural solarization of greenhouses for sanitation by closing them involves dry heating to $60^{\circ} \mathrm{C}$ and higher with a consequent low relative humidity $(\mathrm{RH})(\approx 15 \%)$, thus requiring an extended period for thermal inactivation of pathogens. In an attempt to enhance pathogen control by increasing moisture during the hot hours of the day, various regimes of inoculum moistening were studied. However, wetting inoculum of $\mathrm{Fu}$ sarium oxysporum $\mathrm{f}$. sp. melonis and $F$. oxysporum f. sp. radicis-lycopersici resulted in less effective pathogen control compared with that of dry heating. Fifty percent effective dose $\left(\mathrm{ED}_{50}\right)$ values of thermal inactivation of wetted and dry inoculum for the former pathogen were 18 and 7 days, respectively, and for the latter, a respective 9 and 4 days. This was because wetting resulted in inoculum cooling due to evaporation, which eventually led to its drying. A model describing the drying of wet inoculum in a wetted greenhouse, based on the fact that there was an $\approx 10^{\circ} \mathrm{C}$ difference between greenhouse and ambient temperatures, was proposed. A double-tent system reduced this difference to 1 to $2^{\circ} \mathrm{C}$, reduced moisture loss, and led to improved inoculum inactivation of $F$. oxysporum f. sp. radicis-lycopersici. Thus, the $\mathrm{ED}_{50}$ value of thermal inactivation was reduced from 15 days to 1 day, because this system provided both high temperature $\left(\approx 60^{\circ} \mathrm{C}\right)$ and high $\mathrm{RH}(\approx 100 \%)$, resulting in effective wet heating.

Additional keywords: space solarization.
Sanitation is an important component in greenhouse crop management, because various soilborne pathogens usually bridge their survival between growing seasons by means of resting structures that exist either in the soil or aboveground. Sanitation aims to reduce or eliminate the pest population from all sources, thus breaking the continuity of pathogen survival in time and space between crops $(3,11,12)$. Soil disinfestation (e.g., fumigation or solarization) in greenhouses before planting is routine procedure. Nevertheless, it does not eliminate the inoculum remaining from the previous season, which adheres to the greenhouse structure (such as walls and poles [5,7]), and could become a source for reinfestation of the disinfested soil. Therefore, structural sanitation of the greenhouse, e.g., by physical or chemical means, has to be carried out as a complementary management tool $(3,18)$.

Greenhouse structural (space) solarization is a thermal, nonchemical approach to structural sanitation and is carried out by closing the greenhouse for a certain period of time during the appropriate season. As a consequence, the temperature is raised to high levels that may enable the control of pathogens persisting on the greenhouse structure or even in the soil $(9,18)$. This is a modification of an approach previously developed for soil solarization and sanitation $(1,6,8)$.

Climatic conditions prevailing in the greenhouse during structural solarization can be regarded as dry heating under fluctuating conditions, because the maximal temperature rises to $60^{\circ} \mathrm{C}$ or higher while relative humidity $(\mathrm{RH})$ drops to $\approx 15 \%(9,18)$. Dry heating is less effective in the thermal inactivation of pathogens than wet heating $(17,18)$ and therefore structural solarization

Corresponding author: J. Katan; E-mail address: katan@agri.huji.ac.il

Publication no. P-2003-1204-01R

(c) 2004 The American Phytopathological Society needs to be extended for several weeks (18). Hence, means for improving disinfestation methods are being sought.

The soilborne plant pathogen Fusarium oxysporum f. sp. radicis-lycopersici W.R. Jarvis \& Shoemaker causes Fusarium crown and root rot in tomato. This pathogen produces chlamydospores in the soil and macroconidia on the stems, which are airborne and can be disseminated, contaminating the greenhouse structure $(14,16)$. F. oxysporum f. sp. melonis W.C. Snyder \& H.N. Hans causes wilt in muskmelon. Structural solarization is essential when such pathogens are involved. The objective of this work was to examine the possibility of enhancing thermal inactivation under structural solarization conditions by manipulating moisture regime in the greenhouse.

\section{MATERIALS AND METHODS}

Media. Potato dextrose agar was used to isolate fungi from diseased plants (19). A modified Fusarium-selective medium (FSM) (5) was utilized for enumeration of Fusarium propagules. Czapek-Dox medium (CDM) (19) was used to grow inoculum for pathogenicity tests. Water agar $(0.1 \%$ agar $)$ supplemented with $0.1 \% \mathrm{MgSO}_{4} \cdot 7 \mathrm{H}_{2} \mathrm{O}$ was used to suspend soil samples for soil dilution.

Inocula. Chlamydospores of $F$. oxysporum f. sp. melonis, isolated from diseased muskmelon plants, were produced in soil by incubating conidia for 100 to 120 days at $27^{\circ} \mathrm{C}$, after which only chlamydospores remained in the soil (4). The infested soil was air dried and stored at $8^{\circ} \mathrm{C}$.

Soil samples from fields with diseased tomato plants naturally infected with $F$. oxysporum f. sp. radicis-lycopersici were collected at Kikar Sedom Experimental Station. The soil samples, air dried at room temperature, served as a natural inoculum consisting of chlamydospores, as verified microscopically, and were stored at $5^{\circ} \mathrm{C}$ until use (18). 
Soils. Two soils were used: (i) a natural agricultural sandy soil from Rehovot $(0.4 \%$ organic matter, $96.2 \%$ sand, $0.0 \%$ silt, and $3.8 \%$ clay, wt $/ \mathrm{wt}$ [pH 6.9]), and (ii) a natural agricultural sandy soil from Ein-Tamar $(0.1 \%$ organic matter, $93.9 \%$ sand, $4 \%$ silt, and $2 \%$ clay, wt/wt $[\mathrm{pH} 8.1])$. The moisture content of the airdried soil was $0.6 \%$, wt/wt.

Structural solarization greenhouse experiments. Experiments were performed essentially as described (18) in an experimental greenhouse (The Hebrew University Experimental Farm, Rehovot, Israel) during the summer season (May to October), unless otherwise stated. The greenhouse was constructed with a glass roof and polycarbonate walls. Structural solarization was performed by closing the greenhouse for the indicated period. Its effectiveness in pathogen control was assessed by exposing nylon net bags containing the inoculum $(3 \mathrm{~g})$ in four replicates per treatment. The bags were hung with strings on horizontal metal supports $1 \mathrm{~m}$ above the ground in the middle of the greenhouse. At the selected time intervals, the inoculum bags were removed in the morning $(0700 \mathrm{~h})$ and brought to the laboratory to assess inoculum viability.

Meteorological data. Temperature and $\mathrm{RH}$ were recorded continuously in all experiments with a micrologger $( \pm 0.05 \%$ of voltage measurements, 21X, Campbell Scientific, Inc., Logan, UT). Data were recorded once a minute and averaged every 10 min. Temperature was measured with T-type thermocouples $\left( \pm 0.5^{\circ} \mathrm{C}\right.$, copper-constantan probes) that were inserted in the center of the inoculum bags. Air temperature and RH were measured with an electronic hygrometer $( \pm 1.5 \% \mathrm{RH}, \mathrm{I}-100$, Rotronic, Bassersdorf, Switzerland) inserted in an aerated meteorological shelter.

Enumeration of pathogen propagules. The density of propagules in the inocula was assayed by the soil-dilution method using FSM (5). Results were expressed as colony-forming units per gram of dry soil (CFU/g). The percent survival was calculated by comparing populations of treated versus untreated inoculum. Inoculum density in the various inoculum batches used ranged between 1,500 and 4,000 CFU/g. Colonies of $F$. oxysporum growing on FSM were randomly transferred to CDM and assessed for pathogenicity on the respective host, as previously described (7), to verify their identity.

Inoculum wetting experiments. These experiments were performed at the Rehovot Experimental Farm. Wetting regimes were dry (without wetting) and night irrigation for $4 \mathrm{~h}$ only or plus 30-min irrigations one, two, or three times daily. Irrigation was applied by a minisprinkler close to the inoculum site. The de-

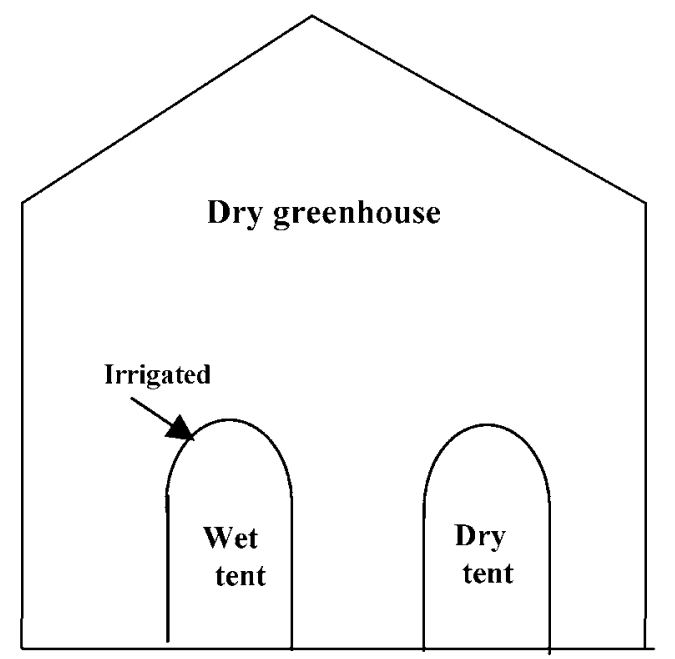

Fig. 1. A diagram of the tents system composed of wet and dry tents inside a dry greenhouse. The wet tent was irrigated for $5 \mathrm{~h}$ every night. Inoculum of Fusarium oxysporum f. sp. radicis-lycopersici was exposed in each tent. pendence of the inoculum temperature on its water content also was studied. During this trial, air-dried inoculum samples in nylon net bags ( $3 \mathrm{~g}$ ) were water-saturated, placed in a closed greenhouse during structural solarization, and water content was assessed every $10 \mathrm{~min}$ by weighing six bags concomitantly with temperature recording. Greenhouse atmosphere wetting experiments were carried out at Kfar Silver's glass educational greenhouse (Southern Israel, near Ashkelon). Inoculum was exposed to structural solarization as described previously. Plot dimensions were 4.0 by 2.5 by $3 \mathrm{~m}$. Atmosphere wetting was manipulated by irrigation of the whole greenhouse volume using minisprinklers for $6 \mathrm{~h}$ each night. Part of the inoculum was exposed to direct wetting treatment (wet inoculum), whereas the other part was covered with a plastic box to avoid wetting (dry inoculum). Four replicates were collected every sampling period. RH was measured $150 \mathrm{~cm}$ above the inoculum site and $50 \mathrm{~cm}$ above the sprinklers.

Enhancement of inoculum thermal inactivation. A system consisting of dry and wet tents inside the closed greenhouse was set up (Fig. 1). Tents dimensions were 2 by 2 by $3 \mathrm{~m}$. The tents were covered with polyethylene sheets (of $0.1 \mathrm{~mm}$ thick). The inoculum was exposed in each tent as described previously for structural solarization experiments. The wet tent and the inoculum inside, $F$. oxysporum f. sp. radicis-lycopersici, were wetted by minisprinklers for $5 \mathrm{~h}$ every night for the purpose of maintaining high RH during the day. The second tent and the greenhouse itself were kept dry. Meteorological data were recorded in the tents and in the inoculum bags. Four replicates were collected every sampling period.

Statistical analyses. Greenhouse and simulation experiments were repeated at least once. Variance between experimental trials was small, and average results were calculated. Analyses included analysis of variance and calculations of standard error. Differences between means were detected using Duncan's new multiple range test. SAS program (release 6.04 for $\mathrm{PC}$ and 6.12 for Windows; SAS Institute, Cary, NC) was used for all statistical analyses.

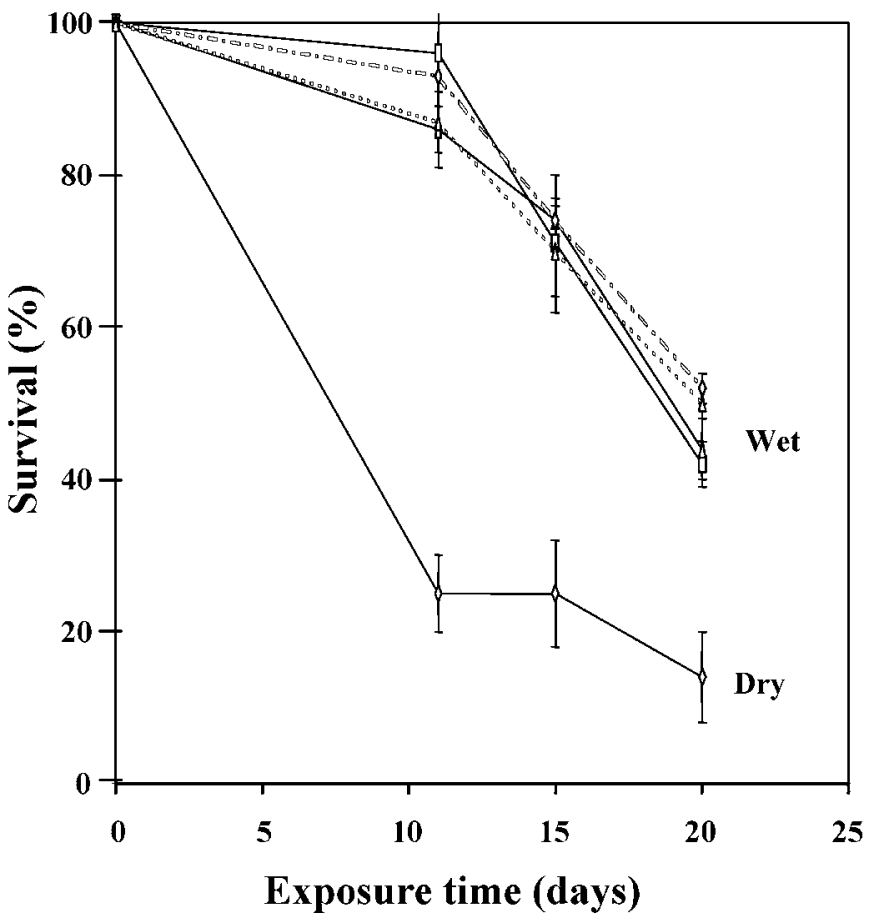

Fig. 2. Survival of Fusarium oxysporum f. sp. melonis soil inoculum under dry heat and under various wetting regimes during structural solarization in a closed greenhouse (wetting regimes ranged from two to five irrigations per day at a duration of $30 \mathrm{~min}$ each). Bars represent \pm standard error. 


\section{RESULTS}

Effect of wetting on inoculum thermal inactivation. Inocula of $F$. oxysporum f. sp. radicis-lycopersici and $F$. oxysporum f. sp melonis were exposed each year from 1992 to 1998 to structural solarization during the summers, and their viability with time and meteorological data were recorded. Viability of pathogens de-

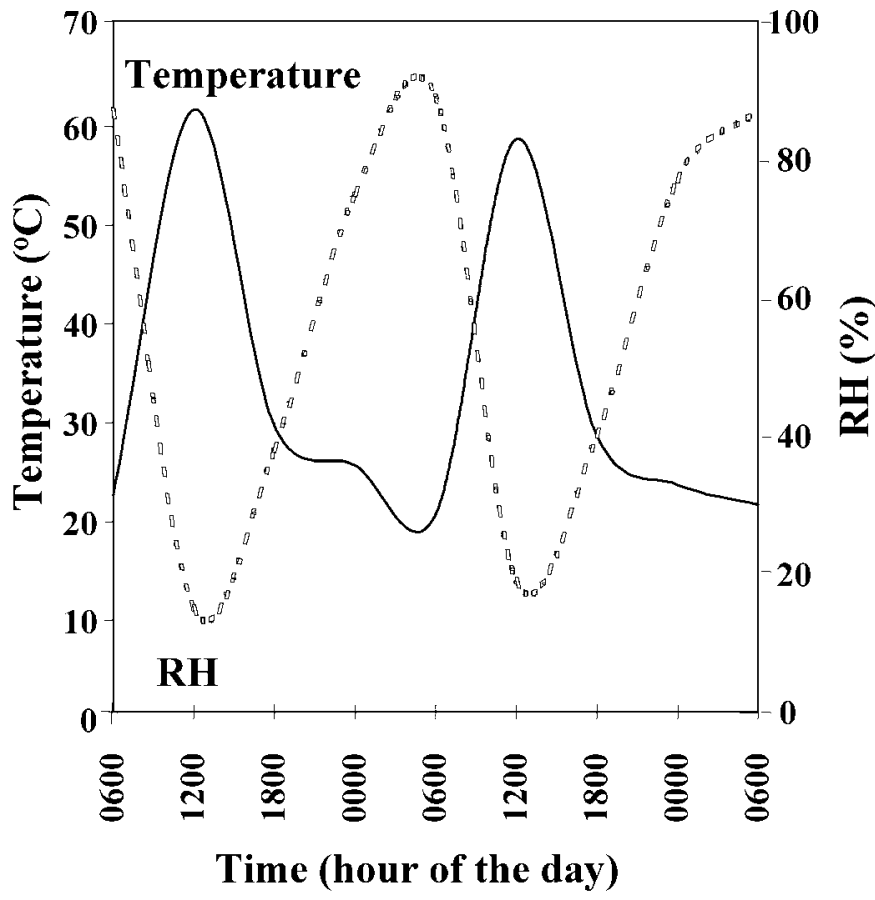

Fig. 3. Typical temperature and relative humidity $(\mathrm{RH})$ data during $48 \mathrm{~h}$ of structural solarization.

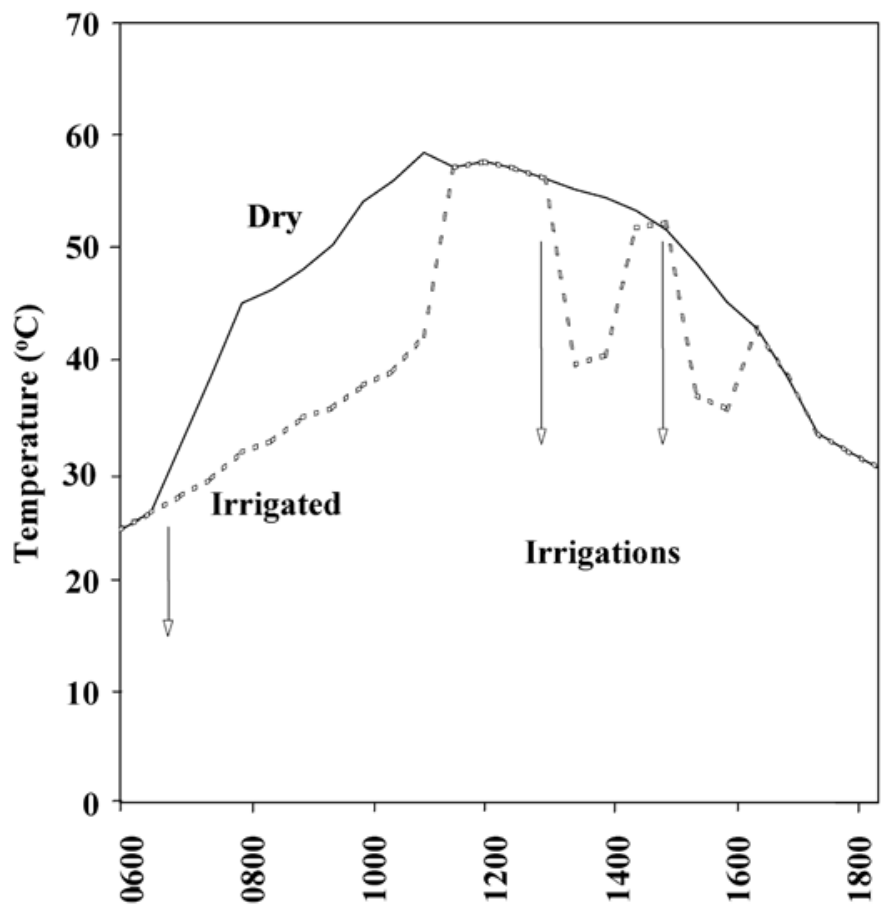

Time (hour of the day)

Fig. 4. Typical temperature regime in dry and irrigated $(30 \mathrm{~min}$ each irrigation, indicated by arrows) soil inoculum (Fusarium oxysporum f. sp. melonis) during structural solarization. Note immediate cooling after each irrigation in the hot hours. clined at various rates, e.g., $80 \%$ of the population was reduced after 7 to 42 days of structural solarization depending on the tested pathogen, inoculum type, and level of heating (data not shown), thus confirming previous results (18). A typical pattern of survival under structural solarization (dry conditions) is presented in Figure 2, showing a rapid decline in survival during the first 10 days to about $25 \%$ followed by a slower rate of decline. The maximal temperatures exceeded $60^{\circ} \mathrm{C}$, while the concomitant $\mathrm{RH}$ decreased to $15 \%$ (Fig. 3). We examined the possibility of enhancing thermal inactivation of $F$. oxysporum $\mathrm{f}$. sp. melonis by wetting the inoculum. Several wetting regimes were examined, but contrary to expectations, all the wetted treatments resulted in improved survival rather than in its reduction (Fig. 2). Temperature data (Fig. 4) showed that inoculum wetting by irrigation and the consequent evaporation reduced its temperature by $\approx 20^{\circ} \mathrm{C}$. Under these conditions, temperature did not exceed 35 to $40^{\circ} \mathrm{C}$. Within an hour, temperatures rose to $60^{\circ} \mathrm{C}$. This process was further studied.

The irrigation study indicated that wetting and cooling are closely connected. Results of the study regarding the dependence of inoculum temperature on its water content (Fig. 5) revealed that as long as the inoculum water loss was lower than $95 \%$, its temperature did not exceed $40^{\circ} \mathrm{C}$. Only after $\approx 2 \mathrm{~h}$ (when water loss was $95 \%$ or higher) did the temperature increase rapidly to $55^{\circ} \mathrm{C}$ and higher. This confirmed our assumption that under regular greenhouse conditions an increase in temperature takes place only after extreme drying of the inoculum. This phenomenon is expected to occur when the RH of the surroundings is low, allowing water to evaporate from the inoculum and maintaining it at the wet-bulb temperature. Hence, an optimal combination of both high temperature and high $\mathrm{RH}$ could not be achieved with this wetting regime.

In another attempt to prevent evaporation of the inoculum moisture to the greenhouse atmosphere and its subsequent cooling, using a different wetting regime, the whole greenhouse was irrigated every night for $6 \mathrm{~h}$. Results (Fig. 6) showed that, similar to the previous experiment (Fig. 2), survival of wet inoculum of $F$.

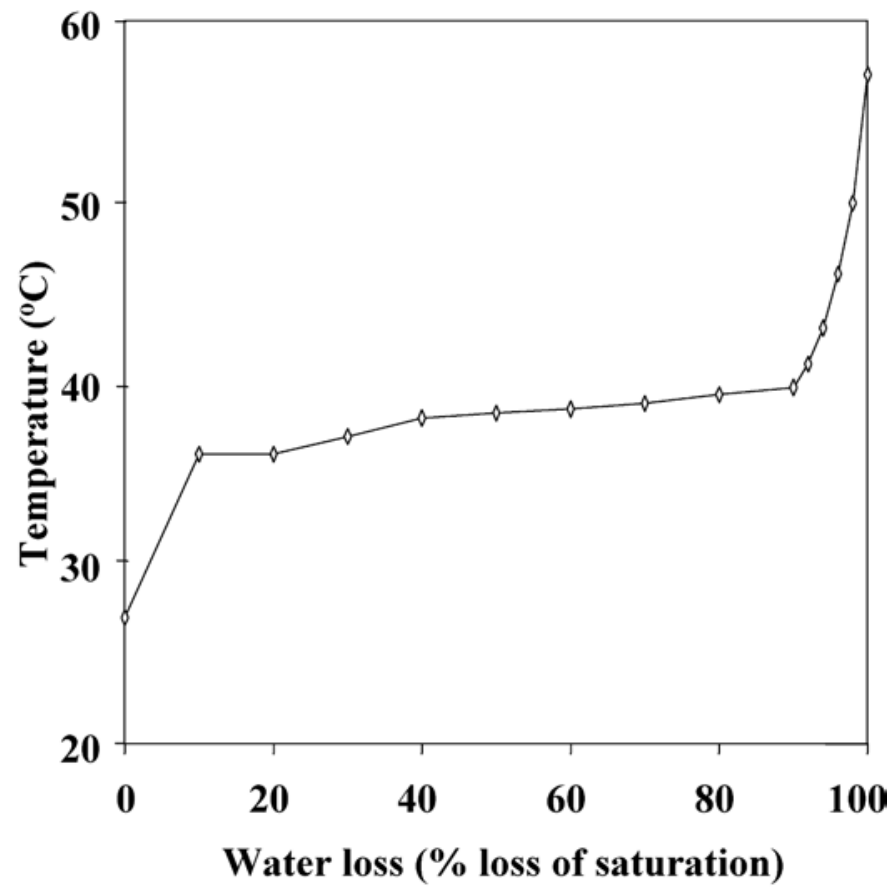

Fig. 5. Effect of water loss from water-saturated inoculum on its temperature. Water-saturated soil inoculum bags were exposed during the hot hours of the day $\left(\approx 55^{\circ} \mathrm{C}\right)$ in a closed greenhouse. Six bags were sampled every $10 \mathrm{~min}$ and weighed and their temperature concomitantly recorded. Standard error values of water loss range from \pm 0.1 to \pm 2 . 
oxysporum f. sp. radicis-lycopersici was higher than that of the dry inoculum under this wetting regime. Temperature and $\mathrm{RH}$ data showed that although $\mathrm{RH}$ was high during part of the day (Fig. 7), a combination of both high temperature and high $\mathrm{RH}$ for long periods could not be achieved with this wetting regime. During the day, until about $1400 \mathrm{~h}$, inoculum temperature remained low and did not exceed $45^{\circ} \mathrm{C}$. Subsequently, temperature rose sharply to $65^{\circ} \mathrm{C}$, while $\mathrm{RH}$ dropped rapidly to $35 \%$.

Based on the above data and those from special simulation experiments (data not shown), we propose a mechanism for inoculum drying in a wet atmosphere in the greenhouse (Fig. 8A). During the first stage, wetting (or irrigation) saturates the greenhouse air. Towards noon, there is a difference between the temperature in the closed greenhouse $\left(\mathrm{T}_{\mathrm{G}}\right)$ and the outside atmosphere $(\mathrm{T})$, which is cooler by $\approx 10^{\circ} \mathrm{C}$. Consequently, the greenhouse wall is cooler than the greenhouse air, because it is in direct

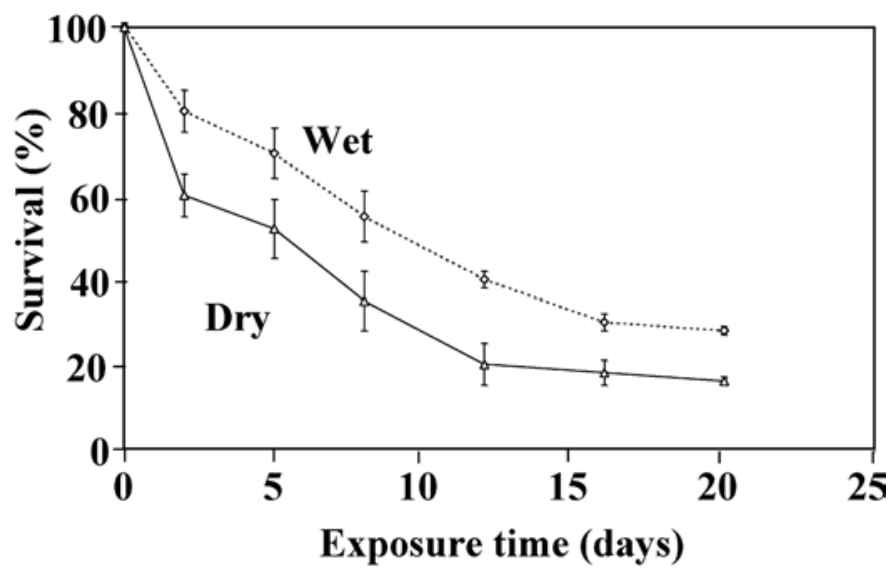

Fig. 6. Survival curves of Fusarium oxysporum f. sp. radicis-lycopersici under structural solarization. Wet indicates both greenhouse space and inoculum were wetted every night by sprinkling; and dry indicates inoculum was kept dry by covering it with a plastic box when the greenhouse was sprinkled. Bars represent \pm standard error.

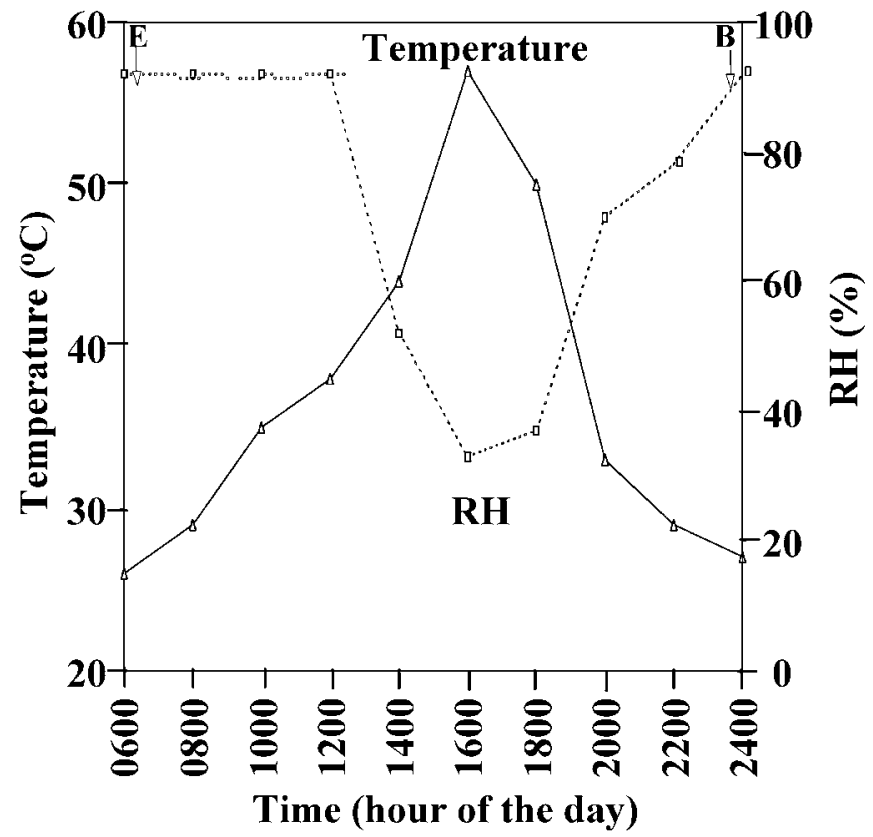

Fig. 7. Inoculum temperature and relative humidity $(\mathrm{RH})$ data during a typical day of the Kfar Silver experiment, measured at a height of $2 \mathrm{~m}$. Sprinkling was carried out every night (from 0000 to $0600 \mathrm{~h}$ ). Daily irrigation period is indicated by arrows ( $\mathrm{B}$ indicates initiation of irrigation; and $\mathrm{E}$ indicates end of irrigation). contact with the cooler external atmosphere. Thus, the air that is in contact with the greenhouse wall cools and loses part of its humidity by condensation. Excess water leaves the system leading to drying of the greenhouse air and the inoculum in about $2 \mathrm{~h}$ (Fig. 5). The incomplete sealing of the greenhouse cover may cause loss of moisture through leaks. This proposed model was the basis for the following attempt to improve the thermal inactivation of inoculum.

Enhancement of thermal inactivation. Because greenhouse drying is due mainly to the temperature difference between the greenhouse atmosphere and external air $\left(\mathrm{T}_{\mathrm{G}}>\mathrm{T}\right)$ (Fig. 8A), a system of dry and wet tents inside the closed greenhouse, described earlier (Fig. 1), was designed to examine this hypothesis. The RH in the wet tent (Fig. 9), which was irrigated every night, remained high (about $100 \%$ ). The temperature difference between the wet tent $\left(\mathrm{T}_{\mathrm{W}}\right)$ and the closed greenhouse air $\left(\mathrm{T}_{\mathrm{I}}\right)$, which served as an insulation layer between the wet tent and the external atmosphere (T), was minimal ( 1 to $2^{\circ} \mathrm{C}$ ) (Figs. $8 \mathrm{~B}$ and 9 ), and therefore, there was almost no moisture loss through condensation. Inoculum temperature in the wet tent increased (to a maximum $60^{\circ} \mathrm{C}$ ), although to a somewhat lower level than the inoculum in the dry
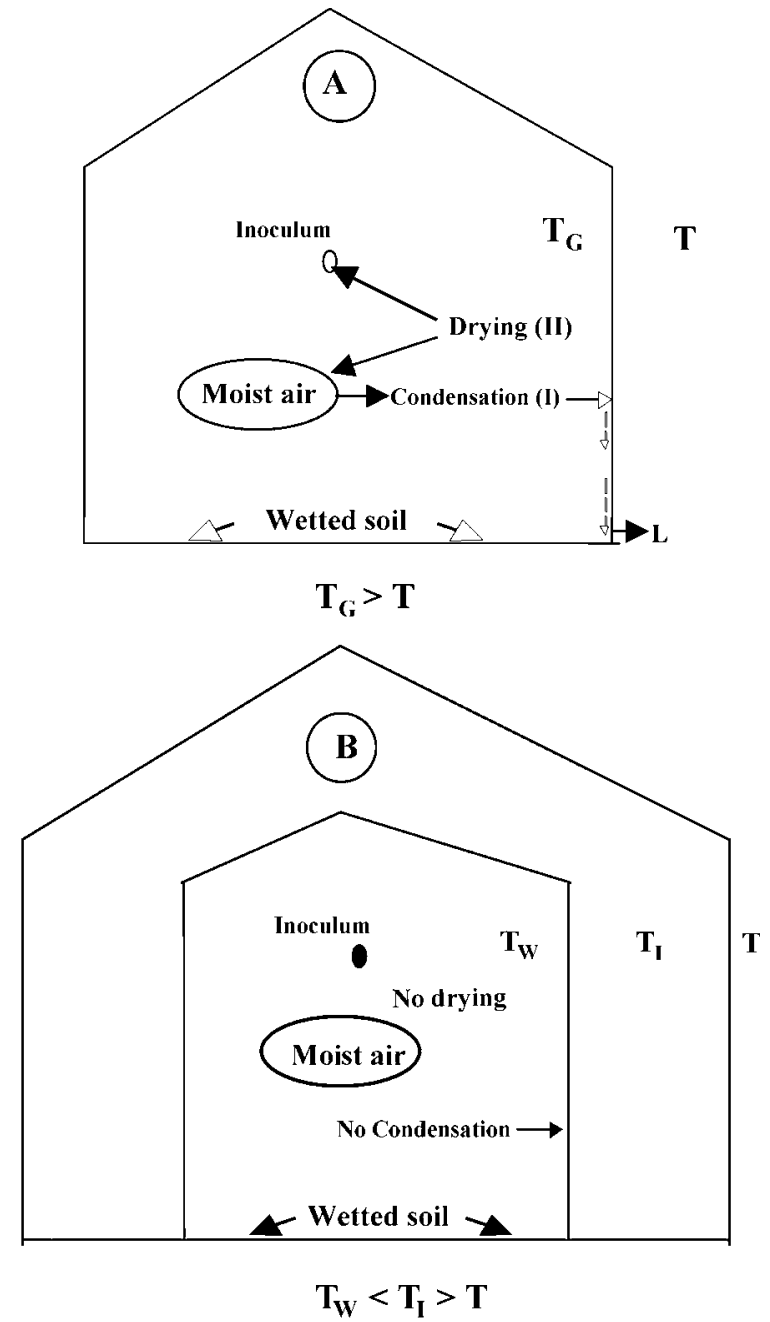

Fig. 8. Diagrams depicting moisture and temperature regimes in two systems. $\mathbf{A}$, A proposed process of drying in a prewetted closed greenhouse. During daytime moist air in the greenhouse $\left(T_{G}\right)$ is warmer than outside air $(T)$. When it contacts the colder wall, a part of its moisture is leaving the system by condensation (I), leading to drying (II) of the greenhouse air and of the wet inoculum in about $2 \mathrm{~h}$. Leakage (L) of moisture may take place due to insufficient sealing of the system. B, Temperature and relative humidity regime in the wet tent in the double tent system (Fig. 1). $\mathrm{T}_{\mathrm{w}}=$ wet tent temperature; $\mathrm{T}_{\mathrm{I}}=$ dry greenhouse temperature (serving as an insulating layer); and $\mathrm{T}=$ ambient temperature. 
tent. This combination of high temperatures for more than $6 \mathrm{~h}$ each day accompanied by high humidity resulted in the rapid inactivation of $F$. oxysporum f. sp. radicis-lycopersici, reaching $100 \%$ mortality within 3 days compared with 30 days in the dry tent (Fig. 10). This is in spite of the fact that the temperature of the inoculum in the dry tent reached $70^{\circ} \mathrm{C}$ for $4 \mathrm{~h}$ each day. $\mathrm{RH}$ in the dry tent during the hot period of the day was 15 to $25 \%$ (Fig. 9).

\section{DISCUSSION}

We studied the moisture regime prevailing during structural solarization in an attempt to enhance pathogen control by increasing moisture during the hot hours of the day. This, since climatic conditions prevailing during the day under regular structural solarization are characterized by high temperature and low $\mathrm{RH}$, leading to low effectiveness of thermal control of pathogens.

Wet heating is much more effective at thermal inactivation of pathogens, as demonstrated in various studies $(2,13)$. Survival curves of Alternaria porri f. sp. solani spores during exposure to $53^{\circ} \mathrm{C}$ and $\mathrm{RH}$ levels of 14,51 , and $75 \%$ showed maximal longevity of 40,4 , and 3 days, respectively (15). Wet heating was also more effective in controlling $F$. oxysporum $\mathrm{f}$. $\mathrm{sp}$. radicislycopersici and Sclerotium rolfsii (18). Under conditions of wet heat, inactivation of microorganisms results from denaturation of their enzymes and structural proteins. Typically, the temperature at which denaturation occurs varies inversely with the amount of water present (17). In dry-heat processes, the moisture content is considered to be a limiting factor and the primary lethal process can be described as oxidation of cell constituents.

Attempts to enhance thermal inactivation by wetting only the inoculum led to the undesirable result of higher survival (Figs. 2 and 6). Wetting of the inoculum by irrigation was followed by a decrease in its temperature (Fig. 4) due to water evaporation from the wetted inoculum and its consequent cooling. Evaporation, which is an endothermic energy-consuming process, cools the wet inoculum sample (Fig. 5) until equilibrium is reached at the wet-bulb temperature (10). As long as the water activity $\left(\mathrm{a}_{\mathrm{w}}=\right.$ $\mathrm{RH} / 100$ ) of the moistened inoculum sample is higher than that of the greenhouse atmosphere (which is about 0.2 between the hours of 1000 and 1600 [18]), there is evaporation of water vapor from

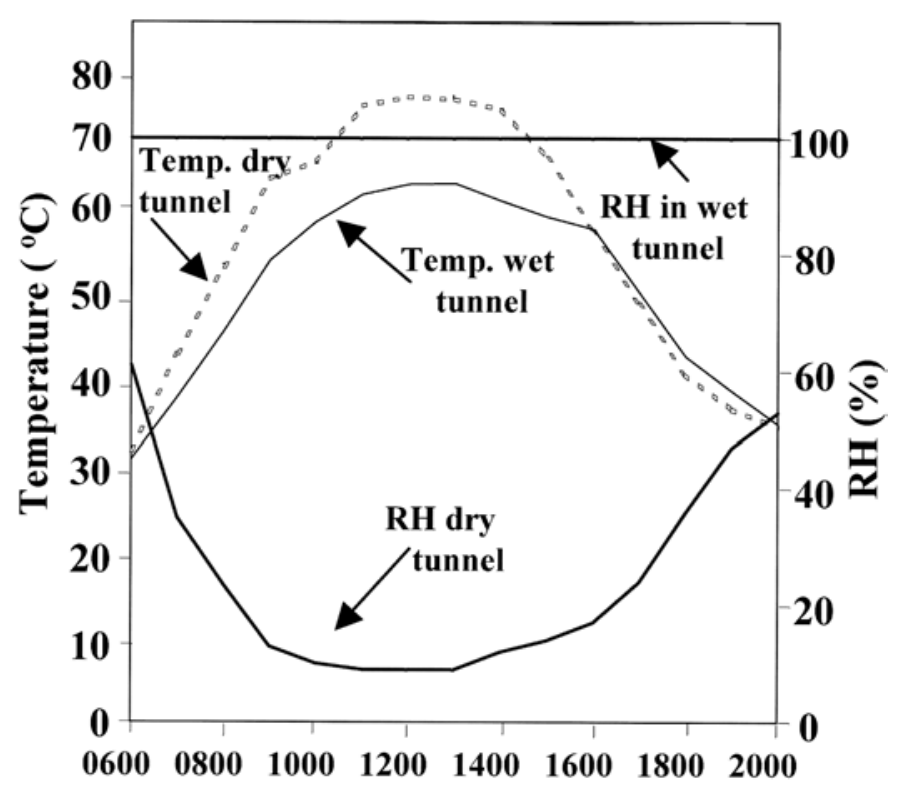

Time (hour of the day)

Fig. 9. Temperature and relative humidity $(\mathrm{RH})$ regime in dry and wet tents inside a closed greenhouse. the inoculum sample to the greenhouse atmosphere. Evaporation keeps the moist sample at about 35 to $40^{\circ} \mathrm{C}$, which is a nonlethal temperature. Only when moisture reaches $5 \%$ of the initial moisture level (in this specific medium) does temperature increase to $55^{\circ} \mathrm{C}$ (Fig. 5). We can therefore assume that under regular greenhouse conditions an increase in temperature occurs only after extreme drying of the prewetted inoculum, which consequently leads to increased thermal tolerance. Until that point, temperature is kept low at the wet-bulb temperature.

A model based on preliminary experiments studying the cooling process of a prewetted soil inoculum sample exposed to an air-saturated closed greenhouse is illustrated in Figure 8A. Greenhouse air temperature $\left(\mathrm{T}_{\mathrm{G}}\right)$ is higher during the hot hours by about $10^{\circ} \mathrm{C}$ than the ambient temperature $(\mathrm{T})$. Therefore, when the temperature of the greenhouse wall equals or is lower than dew-point temperature, excess water condenses there and leaves the system, causing successive drying of the greenhouse atmosphere and the inoculum. Therefore, as long as the greenhouse atmospheric $\mathrm{RH}$ is about $100 \%$, inoculum temperature is kept at a relatively low level. The temperature rises to about $55^{\circ} \mathrm{C}$ only when the greenhouse atmosphere dries to about $25 \% \mathrm{RH}$. This explains why we failed to enhance thermal inactivation by wetting the entire greenhouse in order to minimize $a_{w}$ differences between the inoculum and the greenhouse atmosphere (Figs. 6 and 7).

We attempted to minimize this difference between the greenhouse and external air, because it is the main cause of drying of wet inoculum, by designing a system of wetted tents inside a closed dry greenhouse. The difference between the temperature cycles in the wet tent (Fig. $\left.8 \mathrm{~B}, \mathrm{~T}_{\mathrm{W}}\right)$ and closed greenhouse $\left(\mathrm{T}_{\mathrm{I}}\right)$ was minimal ( 1 to $2^{\circ} \mathrm{C}$ ), and consequently, $\mathrm{RH}$ remained high and constant during the day (Fig. 9). This led to the desired combination of both high temperature and RH (Fig. 9) and consequently to the rapid and complete thermal inactivation of the pathogen (Fig. 10). Hence, the theoretical solution for enhanced thermal inactivation by structural solarization is to cover the entire greenhouse with an additional layer of plastic sheet, forming a double-layer wall with air insulation in the greenhouse. This

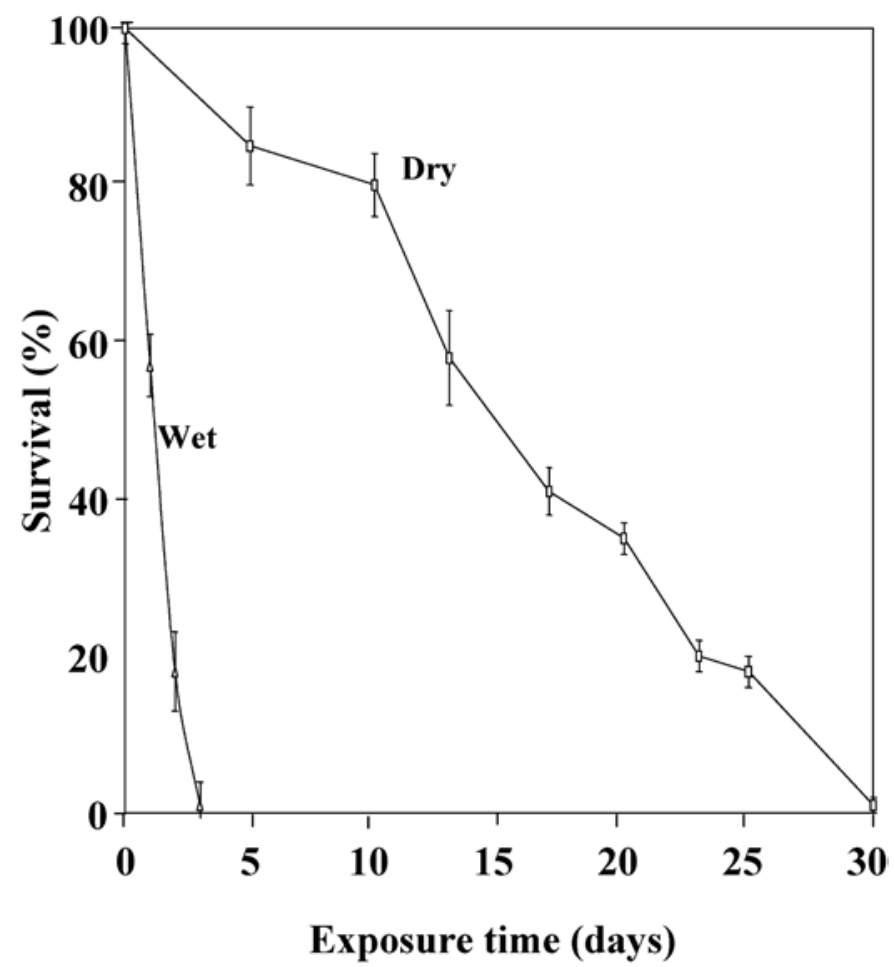

Fig. 10. Survival curves of Fusarium oxysporum f. sp. radicis-lycopersici in wet and dry tents inside a closed greenhouse. Bars represent \pm standard error. 
solution is not practical on a large scale, because the cost of it might be prohibitive. However, a "double-tent" solarization technique in rather small tunnels was recommended in California for improving heating and disinfestation of nematode-infested soil and weed control in soil and other planting media used for framegrown plant nurseries $(20,21)$. This technique ensures a minimum temperature of $70^{\circ} \mathrm{C}$ for $30 \mathrm{~min}$ under wet conditions, which is required for pest inactivation. This approach also can be adopted for small-scale greenhouse growing systems. Improvement of structural solarization also can be achieved by using a clean cover, a new or a washed one, to increase irradiation and heating.

Structural solarization is a nonchemical and simple sanitation tool with the potential to eliminate soilborne and airborne pathogens as well as arthropods and weeds (22). Technologies that enable the maintenance of high moisture during the heating period can enhance pathogen control and thus improve the greenhouse sanitation process.

\section{ACKNOWLEDGMENTS}

This research was supported, in part, by the research fund of the Chief Scientist, Israeli Ministry of Agriculture. We thank S. Saguy, D. Shtienberg, H. Voet, U. Shani, and R. Wallach for advice, and S. Erez, S. Lurie, and Y. Gotlib for technical help.

\section{LITERATURE CITED}

1. Besri, M. 1983. Lutte contre le chancre a Didymella lycopersici de la tomate par chauffage solaire (solarisation) de tuteurs. Phytopathol. Z. 108:333.

2. Dunn, P. H., Barro, S. C., and Poth, M. 1985. Soil moisture affects survival of microorganisms in heated chaparral soil. Soil Biol. Biochem. 17:143-148.

3. Fletcher, J. T. 1984. Diseases of Greenhouse Plants. Longman Scientific \& Technical, London.

4. Gamliel, A., Grinstein, A., Klein, L., Cohen, Y., and Katan, J. 1998. Permeability of plastic films to methyl bromide: Field study. Crop Prot. 17:241-248.

5. Gamliel, A., Katan, T., Yunis, H., and Katan, J. 1996. Fusarium wilt and crown rot of sweet basil: Involvement of soilborne and airborne inoculum. Phytopathology 86:56-62.

6. Garibaldi, A., and Tamietti, G. 1983. Attempts to use soil solarization in closed greenhouses in northern Italy for controlling corky root of tomato. Acta Hortic. 152:271.
7. Katan, T., Shlevin, E., and Katan, J. 1997. Sporulation of Fusarium oxysporum $\mathrm{f}$. sp. lycopersici on stem surfaces of tomato plants and aerial dissemination of inoculum. Phytopathology 87:712-719.

8. Kodama, T., and Fukui, Y. 1979. Solar heating solarization in the closed vinyl house against soil-borne diseases. I. The movements of soil temperature and determination of thermal lethal conditions for some soilborne pathogens. (In Japanese, with English summary.) Bull. Nara Prefect. Agric. Exp. Stn. 10:71.

9. Mahrer, Y., Avissar, R., Naot, O., and Katan, J. 1987. Intensified soil solarization with closed greenhouse: Numerical and experimental studies. Agric. For. Meteorol. 41:325-334.

10. Oke, T. R. 1987. Boundary Layer Climates. Methuen, London.

11. Palti, J. 1980. Cultural Practices and Infectious Crop Diseases. SpringerVerlag, Berlin.

12. Palti, J., and Katan, J. 1997. Effect of cultivation practices and cropping systems on soilborne diseases. Pages 377-396 in: Soilborne Diseases of Tropical Crops. R. J. Hillocks and J. M. Waller, eds. CAB International, Wallingford.

13. Pfeifer, J., and Kessler, H. G. 1994. Effect of relative humidity of hot air on the heat resistance of Bacillus cereus spores. J. Appl. Bacteriol. 77:121-128.

14. Rekah, Y., Shtienberg, D., and Katan, J. 2000. Disease development following infection of tomato and basil foliage by airborne conidia of the soilborne pathogens Fusarium oxysporum f. sp. radicis-lycopersici and $F$. oxysporum f. sp. basilici. Phytopathology 90:1322-1329.

15. Rotem, J. 1968. Thermoxerophyte properties of Alternaria porri f. sp. solani. Phytopathology 58:1284-1287.

16. Rowe, R. C., Farley, J. D., and Coplin, D. L. 1977. Airborne spore dispersal and recolonization of steamed soil by Fusarium oxysporum in tomato greenhouses. Phytopathology 67:1513-1517.

17. Russell, R. C., Hugo, W. B., and Ayliffe, G. A. J. 1992. Heat sterilization. Pages 483-510 in: Principles and Practice of Disinfection, Preservation and Sterilization. 2nd ed. Blackwell Scientific, Oxford.

18. Shlevin, E., Saguy, I. S., Mahrer, Y., and Katan, J. 2003. Modeling the survival of two soilborne pathogens under dry structural solarization. Phytopathology 93:1247-1257.

19. Singleton, L. L., Mihail, J. D., and Rush, C. M. 1992. Methods for Research on Soilborne Phytopathogenic Fungi. The American Phytopathological Society, St. Paul, MN.

20. Stapleton, J. J., McHenry, M. V., and Ferguson, L. 1999. Methyl bromide alternatives: CDFA approves a solarization technique to ensure against nematode pest infestation of containerized nursery stock. UC Plant Prot. Q. 9:14.

21. Stapleton, J. J., Prather, T. S., Mallek, S. B., Ruiz, T. S., and Elmore, C. L. 2000. High temperature solarization for weed control in container soil and potting mixes. Proc. 52nd Annu. Conf. Calif. Weed Sci. Soc. 52:204-207.

22. Tamietti, G., and Valentino, D. 2001. Soil solarization: A useful tool for control of Verticillium wilt and weeds in eggplant crops under plastic in the Po valley. J. Plant Pathol. 83:173-180. 